\title{
Protective effect of ethyl acetate extract of Ishige okamurae against carbon tetrachloride-induced acute liver injury in rats
}

\author{
Sohi Kang ${ }^{1, \dagger}$, Wonjun Yang1, ${ }^{1, \dagger}$ Hanseul Oh${ }^{1, \dagger}$, Yeonji Bae ${ }^{1, \dagger}$, Meejung Ahn' ${ }^{2}$, Min Chul Kang ${ }^{3}$, \\ Ryeo Kyeong Ko ${ }^{3}$, Gi Ok Kim³, Jun Hwa Lee ${ }^{4}$, Jin Won Hyun ${ }^{5}$, Changjong Moon ${ }^{6}$, Taekyun Shin ${ }^{1, *}$ \\ ${ }^{1}$ Laboratory of Veterinary Anatomy, College of Veterinary Medicine and Veterinary Medical Research Institute, \\ Jeju National University, Jeju 690-756, Korea \\ Departments of ${ }^{2}$ Anatomy, and ${ }^{5}$ Biochemistry, College of Medicine, Jeju National University, \\ Jeju 690-756, Korea \\ ${ }^{3}$ Jeju Technopark, Jeju 690-121, Korea \\ ${ }^{4}$ Department of Pediatrics, Samsung Changwon Hospital, School of Medicine, Sungkyunkwan University, \\ Changwon 630-723, Korea \\ ${ }^{6}$ Department of Veterinary Anatomy, College of Veterinary Medicine, Chonnam National University, \\ Gwangju 500-757, Korea
}

(Received: August 17, 2011; Revised: September 26, 2011; Accepted: September 27, 2011)

\begin{abstract}
Several compounds and extracts isolated from a brown alga, Ishige (I.) okamurae, exhibit anti-oxidant and anti-inflammatory effects. The present study investigated whether the ethyl acetate (EtOAc) fraction of I. okamurae (EFIO) could ameliorate carbon tetrachloride $\left(\mathrm{CCl}_{4}\right)$-induced hepatotoxicity in rats. Sprague-Dawley rats were intraperitoneally (i.p.) administered with EFIO at 10 or $50 \mathrm{mg} / \mathrm{kg}$ per day for 2 consecutive days before $\mathrm{CCl}_{4}$ injection $(3.3 \mathrm{~mL} / \mathrm{kg}$, i.p.). Twenty four hours later, the rats were anesthesized with diethyl ether and dissected. Pretreatment with EFIO significantly reduced the increased serum levels of alanine aminotransferase and aspartate aminotransferase in $\mathrm{CCl}_{4}$-treated rats. Pretreatment with EFIO also significantly inhibited the reduced activities of superoxide dismutase and catalase in the $\mathrm{CCl}_{4}$-injured liver. Histopathological evaluations showed that hemorrhage, hepatocyte necrosis, inflammatory cell infiltration, and fatty degeneration induced by $\mathrm{CCl}_{4}$ treatment were ameliorated by the administration of EFIO. Additionally, liver immunohistochemical analyses revealed the marked reduction in ED1-positive monocyte-like macrophages in EFIO-pretreated rats given $\mathrm{CCl}_{4}$. These results suggest that $\mathrm{EFIO}$ ameliorates $\mathrm{CCl}_{4}$-induced liver injury, possibly through the inhibition of oxidative stress.
\end{abstract}

Keywords : antioxidant, carbon tetrachloride, hepatoprotection, Ishige okamurae, serum chemistry

\section{Introduction}

Carbon tetrachloride $\left(\mathrm{CCl}_{4}\right)$ is a well-known hepatotoxicant that induces liver injury in experimental animals. This model has been widely used for the evaluation of the therapeutic potential of drugs as well as study of the mechanisms of liver injury, since it is similar to human liver disease from the standpoint of morphology to biochemical features of the cellular lesions [15].

Biochemically, when the metabolism of $\mathrm{CCl}_{4}$ is initiated by NADPH-dependent cytochrome P-450 enzyme, trichloromethyl radicals $\left(\cdot \mathrm{CCl}_{3}\right)$ that are produced in liver microsomes react with $\mathrm{O}_{2}$ to form trichloromethyl peroxyl radicals $\left(\mathrm{Cl}_{3} \mathrm{COO} \bullet\right)$, which peroxidate membrane lipids [13]. The cleavage products of the lipid peroxides: malondialdehyde, 4-hydroxy-2-pentenal, 2,4-hexadienal, 4-hydroxy-2-nonenal, are toxic and cause the breakdown of the rough endoplasmic reticulum (rER) structure, decreased activity of rER enzymes and inhibit protein synthesis, which leads to an alteration in the fatty content of the liver that is linked to hepatocellular necrosis [5].

This $\mathrm{CCl}_{4}$-induced hepatic injury is characterized by two sequential phases: a direct oxidative stress leading to hepatocyte death in the first phase [13], and secondary

\footnotetext{
*Corresponding author

Tel: +82-64-754-3363, Fax: +82-64-756-3354

E-mail: shint@jejunu.ac.kr

These authors contributed equally to this work.
} 
damage from activated hepatic macrophages (Kupffer cells) through the release of inflammatory mediators (i.e., tumor necrosis factor alpha) [3, 4]. These are morphologically visualized in the form of the central lobular necrosis of the liver. Because of the direct involvement of oxidative stress in $\mathrm{CCl}_{4}$-induced hepatic injury, it is conceivable that antioxidants may ameliorate $\mathrm{CCl}_{4}$-induced liver damage.

Ishige (I.) okamurae (Phylum Phaeophyta, Class Phaeophyceae, Order Chordariales, Family Ishigeaceae) is an edible brown alga that has been collected from the coast of Jeju island of Korea [12].

Several studies have reported that the extracts and compounds originated from I. okamurae possess free radical scavenging activity $[7,8,16]$ and anti-inflammatory activity $[10,11]$. Thus, we considered that ethyl acetate (EtOAc) fraction I. okamurae (EFIO) may be useful in the prevention of various hepatic damages induced by oxidative stress and inflammation. However, little is known about the protective effect of compounds derived from $I$. okamurae against $\mathrm{CCl}_{4}$-induced hepatic injury.

The aim of this study was to examine whether EFIO protects against $\mathrm{CCl}_{4}$-induced hepatotoxicity in rats.

\section{Materials and Methods}

\section{Fractionation of I. okamurae}

The brown alga I. okamurae was collected from the coast of Sungsanri, Jeju Island, in July 2009. The samples were washed three times with water to remove salt, epiphytes, and sand attached to the surface, and then carefully rinsed with fresh water. The samples were dried at $60^{\circ} \mathrm{C}$ for $24 \mathrm{~h}$ in an oven and then ground in a grinder prior to extraction. The shade-dried whole plant of I. okamurae $(2,900 \mathrm{~g})$ was extracted with $80 \%$ aqueous methanol with stirring for 2 days at room temperature. The filtrate was concentrated under reduced pressure and freeze-dried to create a powder. The powdered extract $(311.5 \mathrm{~g})$ was suspended in water $(2.0 \mathrm{~L})$ and successively partitioned with $\mathrm{n}$-hexane $(n$ Hex), methylene chloride $\left(\mathrm{CH}_{2} \mathrm{Cl}_{2}\right)$, EtOAc, and $\mathrm{n}$ butanol $(n-\mathrm{BuOH})$. The EFIO was used for this experiment because EFIO contains anti-oxidant diphlorethohydroxycarmalol $[1,8]$ as well as fucoxanthin [10].

\section{Experimental animals}

Female Sprague Dawley rats $(150 \sim 200 \mathrm{~g})$, 6 10weeks-old, were purchased from Orient Bio (Korea).
The rats were housed in plastic cages and maintained at $23 \pm 2^{\circ} \mathrm{C}$ under a $12 \mathrm{~h}: 12 \mathrm{~h}$ light-dark cycle. Feed was 5L79 rat formula (PMI Nutrition, USA). Feed and water were given ad libitum. All experimental procedures were conducted in accordance with the Guidelines for the Care and Use of Laboratory Animals at Jeju National University, Korea.

\section{Optimal dose for in vivo preliminary study}

Twenty five healthy female Sprague Dawley rats were randomly assigned to five experimental groups (five rats/ each group). EFIO was dissolved in phosphate-buffered saline (PBS) and used for injection. To determine the optimal dose of EFIO, rats were intraperitoneally injected with $0,10,50,100$ and $200 \mathrm{mg} / \mathrm{kg}$ of EFIO once daily for 2 consecutive days. Body weights of the rats were checked daily for 1 week. Rats treated with over $100 \mathrm{mg}$ / $\mathrm{kg}$ of EFIO showed a decreased body weight. In all subsequent experiments, the EFIO dose was 10 and 50 $\mathrm{mg} / \mathrm{kg}$.

\section{Treatment with $\mathrm{EFIO}$ prior to $\mathrm{CCl}_{4}$ injection}

EFIO dissolved in PBS was used for intraperitoneal (i.p.) injection (10 or $50 \mathrm{mg} / \mathrm{kg}$ body weight) for 2 consecutive days before $\mathrm{CCl}_{4}$ injection. As a control, only PBS vehicle was injected into rats that received $\mathrm{CCl}_{4}$. The rats were divided ( $\mathrm{n}=5$ per group) into a normal control, $10 \mathrm{mg} / \mathrm{kg}$ EFIO-treated group, $50 \mathrm{mg} / \mathrm{kg}$ EFIO-treated group, vehicle-treated $\mathrm{CCl}_{4}$ group, $10 \mathrm{mg}$ / $\mathrm{kg}$ EFIO-treated $\mathrm{CCl}_{4}$ group, and $50 \mathrm{mg} / \mathrm{kg}$ EFIO-treated $\mathrm{CCl}_{4}$ group. To induce acute liver injury, a $1: 1(\mathrm{v} / \mathrm{v})$ mixture of the $\mathrm{CCl}_{4}$ and sterile olive oil was injected i.p. $(3.3 \mathrm{~mL} / \mathrm{kg}$ ). Rats were fasted and sacrificed $24 \mathrm{~h}$ after $\mathrm{CCl}_{4}$ injection.

\section{Preparation of serum}

After $24 \mathrm{~h}$ after $\mathrm{CCl}_{4}$ injection, the rats were anesthetized using diethyl ether for the sampling of the blood and liver. Blood samples were collected from heart or infraorbital venous plexus. These were allowed to coagulate at room temperature, and were centrifuged at $3,000 \mathrm{~g}$ for $15 \mathrm{~min}$ at room temperature to collect the serum fraction. The serum was separated from the blood and stored at $20^{\circ} \mathrm{C}$ before assay.

\section{Alanine aminotransferase and aspartate ami- notransferase assays}

The serum levels of alanine aminotransferase (ALT) 
and aspartate aminotransferase (AST) were measured as assays of liver function. ALT and AST levels were measured using commercially available kits (Fujifilm, Japan) according to the manufacturer's instructions and were evaluated using a Fuji Dri-Chem3500 Clinical Chemistry Analyzer (Fujifilm, Japan). Serum was diluted if the value of the measurement was out of range.

\section{Detection of liver superoxide dismutase and cata- lase activities}

The excised livers of experimental rats were immediately frozen and the tissue was homogenized in a glass-Teflon homogenizer with $50 \mathrm{mM}$ phosphate buffer ( $\mathrm{pH} 7.4)$ to obtain a $1: 9(\mathrm{w} / \mathrm{v})$ whole homogenate. The homogenates were then centrifuged at $11,000 \mathrm{~g}$ for $10 \mathrm{~min}$ at $4^{\circ} \mathrm{C}$ to remove cellular debris. The protein content of the supernatant was determined using the Bradford method. For detection of superoxide dismutase (SOD) activity, $50 \mu \mathrm{g}$ liver protein was added to 500 $\mathrm{mM}$ phosphate buffer ( $\mathrm{pH} 10.2$ ) and $1 \mathrm{mM}$ epinephrine. Epinephrine rapidly undergoes auto-oxidation at $\mathrm{pH} 10$ to produce the pink-colored product adrenochrome, which was assayed at $480 \mathrm{~nm}$ using an ultraviolet/visible spectrophotometer operating in the kinetic mode. SOD inhibits the auto-oxidation of epinephrine. The rate of inhibition was monitored at $480 \mathrm{~nm}$, and the amount of enzyme required to produce $50 \%$ inhibition was defined as one unit of enzyme activity. The total SOD activity was expressed as units/mg protein [14]. For detection of catalase (CAT) activity, $50 \mu \mathrm{g}$ of liver protein was added to $50 \mathrm{mM}$ phosphate buffer ( $\mathrm{pH} 7.0$ ) and $100 \mathrm{mM}$ hydrogen peroxide $\left(\mathrm{H}_{2} \mathrm{O}_{2}\right)$, and the mixture was incubated for $2 \mathrm{~min}$ at $37^{\circ} \mathrm{C}$. Following incubation, the absorbance of the mixture at $240 \mathrm{~nm}$ was monitored for $5 \mathrm{~min}$. The change in absorbance was proportional to the breakdown of $\mathrm{H}_{2} \mathrm{O}_{2}$ and the CAT activity present in the sample was expressed as units/mg protein [2].

\section{Histopathology}

Liver tissue samples were fixed in $10 \%$ neutral buffered formalin and embedded in paraffin wax and cut into $5 \mu \mathrm{m}$ thick sections, which were stained with hematoxylin and eosin (H\&E) for routine examination. To reveal the fatty changes, fixed frozen sections were stained with Oil red $\mathrm{O}$, which detects neutral triglycerides and lipids.

\section{Immunohistochemical analysis}

Paraffin-embedded liver sections ( $5 \mu \mathrm{m}$-thick) were deparaffinized, treated with citrate buffer $(0.01 \mathrm{M}, \mathrm{pH}$ 6.0 ) in a microwave for $3 \mathrm{~min}$, and then treated with $0.3 \% \mathrm{H}_{2} \mathrm{O}_{2}$ in methyl alcohol for $20 \mathrm{~min}$ to block endogenous peroxidase activity. After three washes with PBS, the sections were incubated with $10 \%$ appropriate sera including normal horse serum, and then with antirat monocyte-like hepatic macrophage primary antibody (ED1; Serotec, UK). Immunoreactivity was visualized with an avidin-biotin peroxidase reaction (Vector Elite; Vector Labs, USA). The peroxidase reaction was developed using a diaminobenzidine substrate kit (Vector Labs, USA). The sections were counterstained with hematoxylin before being mounted.

\section{Statistical analyses}

The data are reported as the mean $\pm \mathrm{SE}$. The data was analyzed using one-way analysis of variance (ANOVA) followed by a Student-Newman-Keuls post hoc test for multiple comparisons. In all cases, a $p$ value $<0.05$ was considered significant.

\section{Results}

Effect of EFIO on serum enzyme activity in $\mathrm{CCl}_{4}$ induced acute liver injury

Biochemical analysis of serum enzymes was performed to verify the protective role of EFIO in $\mathrm{CCl}_{4}$-induced hepatic injury. The activities of serum ALT and AST in normal controls were $71.7 \pm 1.3 \mathrm{IU} / \mathrm{L}$ and $140.7 \pm 1.9$ IU/L, respectively (Table 1 ). There were no significant differences in the levels of serum ALT and AST between either 10 or $50 \mathrm{mg} / \mathrm{kg}$ EFIO-treated groups and normal controls. In vehicle-treated $\mathrm{CCl}_{4}$-intoxicated rats, the activities of serum ALT $(2,986.7 \pm 1,070.8 \mathrm{IU} / \mathrm{L})$ and AST $(7,440.0 \pm 2,404.7 \mathrm{IU} / \mathrm{L})$ were significantly increased compared with those of the normal controls $(p<0.05)$. Treatment with $50 \mathrm{mg} / \mathrm{kg}$ EFIO significantly reduced the activities of serum ALT and AST $(206.7 \pm 127.3 \mathrm{IU} / \mathrm{L}$ and $1,056.0 \pm 470.5 \mathrm{IU} / \mathrm{L}$, respectively; $p<0.05)$. These results were consistent with the view that EFIO ameliorates the increase of serum enzymes (ALT and AST) in $\mathrm{CCl}_{4}$-induced liver injury.

Effect of EFIO on SOD and CAT activity in $\mathrm{CCl}_{4}-$ induced acute liver injury

To investigate anti-oxidant effect of EFIO on $\mathrm{CCl}_{4}$ induced liver injury, the activity of the anti-oxidant enzymes SOD and CAT was evaluated in hepatic tissues. 
Table 1. Effects of pretreatment with ethyl acetate fraction Ishige okamurae (EFIO) on carbon tetrachloride $\left(\mathrm{CCl}_{4}\right)$ induced hepatotoxicity

\begin{tabular}{lcc}
\hline \hline \multicolumn{1}{c}{ Group } & Serum ALT $(\mathrm{U} / \mathrm{L})$ & Serum AST $(\mathrm{U} / \mathrm{L})$ \\
\hline Control & $71.7 \pm 1.3$ & $140.7 \pm 1.9$ \\
EFIO $(10 \mathrm{mg} / \mathrm{kg})$ & $55.0 \pm 14.0$ & $162.3 \pm 11.3$ \\
EFIO $(50 \mathrm{mg} / \mathrm{kg})$ & $46.3 \pm 13.4$ & $207.3 \pm 85.7$ \\
CCl $(3.3 \mathrm{~mL} / \mathrm{kg})$ & $2,987.7 \pm 1,071.9^{\mathrm{a}}$ & $7,440.0 \pm 2,404.8^{\mathrm{a}}$ \\
EFIO $(10 \mathrm{mg} / \mathrm{kg})+\mathrm{CCl}_{4}$ & $1,693.3 \pm 618.1$ & $6,073.3 \pm 384.4$ \\
EFIO $(50 \mathrm{mg} / \mathrm{kg})+\mathrm{CCl}_{4}$ & $2,076.7 \pm 127.3^{\mathrm{b}}$ & $1,056.0 \pm 470.5^{\mathrm{b}}$ \\
\hline
\end{tabular}

Rats were pretreated with EFIO (10 or $50 \mathrm{mg} / \mathrm{kg}$, i.p.) once daily for 2 consecutive days. $24 \mathrm{~h}$ after the final treatment, the rats were treated with $\mathrm{CCl}_{4}(3.3 \mathrm{~mL} / \mathrm{kg}$, i.p.). Hepatotoxicity was determined $24 \mathrm{~h}$ later by quantifying the serum activities of alanine aminotransferase (ALT) and aspartate aminotransferase (AST). Each value represents the mean \pm SE for three rats.

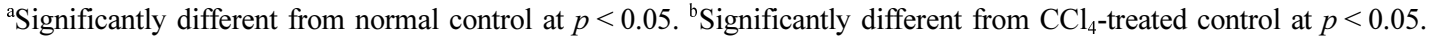

Table 2. Effects of pretreatment with ethyl acetate fraction Ishige okamurae (EFIO) on SOD and CAT in the liver of rats with carbon tetrachloride $\left(\mathrm{CCl}_{4}\right)$

\begin{tabular}{lcc}
\hline \multicolumn{1}{c}{ Group } & SOD $(\mathrm{U} / \mathrm{mg})$ & CAT $(\mathrm{U} / \mathrm{mg})$ \\
\hline Control & $774.6 \pm 55.1$ & $1,519.4 \pm 23.3$ \\
EFIO $(50 \mathrm{mg} / \mathrm{kg})$ & $948.3 \pm 31.8$ & $2,236.2 \pm 150.2^{\mathrm{a}}$ \\
$\mathrm{CCl}_{4}(3.3 \mathrm{~mL} / \mathrm{kg})$ & $255.5 \pm 24.5^{\mathrm{a}}$ & $433.2 \pm 152.8^{\mathrm{a}}$ \\
$\mathrm{EFIO}(50 \mathrm{mg} / \mathrm{kg})+\mathrm{CCl}_{4}$ & $445.6 \pm 51.2^{\mathrm{b}}$ & $1,202.2 \pm 26.8^{\mathrm{c}}$ \\
\hline
\end{tabular}

Rats were pretreated with EFIO $(50 \mathrm{mg} / \mathrm{kg}$, i.p.) once daily for 2 consecutive days. $24 \mathrm{~h}$ after the final treatment, the rats were treated with $\mathrm{CCl}_{4}(3.3 \mathrm{~mL} / \mathrm{kg}$, i.p.). Oxidative stress parameters were determined $24 \mathrm{~h}$ later by quantifying the superoxide dismutase (SOD) and catalase (CAT). Each value represents the mean \pm SE for four rats. ${ }^{a}$ Significantly different from normal control at $p<0.001$. ${ }^{\mathrm{b}}$ Significantly different from $\mathrm{CCl}_{4}$-treated control at $p<0.05$. ${ }^{\mathrm{C}}$ Significantly different from $\mathrm{CCl}_{4}$-treated control at $p<0.001$.

We have chosen one group treated with EFIO $(50 \mathrm{mg} /$ $\mathrm{kg}$ ) because this dose is effective in serum chemistry (Table 1) and compared EFIO (50 mg/kg) group with other control groups as shown in Table 2. The hepatic SOD activity in the vehicle $+\mathrm{CCl}_{4}$ group was significantly reduced by approximately $33 \%$ as compared to the normal controls $(p<0.001)$. However, the SOD activity was significantly increased by $50 \mathrm{mg} / \mathrm{kg}$ EFIO treatment prior to $\mathrm{CCl}_{4}$ treatment $\left(\mathrm{EFIO}+\mathrm{CCl}_{4}\right)$ as compared to the vehicle $+\mathrm{CCl}_{4}$ group $(p<0.05)$ (Table 2$)$. Moreover, the activity of CAT in $\mathrm{EFIO}+\mathrm{CCl}_{4}$ group was significantly decreased by approximately $29 \%$ as compared to the untreated control group $(p<0.001)$. However, pretreatment with EFIO $\left(\mathrm{EFIO}+\mathrm{CCl}_{4}\right)$ increased significantly the CAT activity as compared to the vehicle + $\mathrm{CCl}_{4}$ group $(p<0.001)$ (Table 2$)$.

\section{Histopathological examination}

Histopathological studies also provided important evidence supporting the biochemical analysis and liver antioxidant status. In the normal controls, liver sections showed normal hepatic cells with a well-preserved cytoplasm, a prominent nucleus, and central vein (Fig. 1A). The pathological changes in the livers were not found in rats treated with 10 or $50 \mathrm{mg} / \mathrm{kg}$ EFIO (data not shown). The livers of $\mathrm{CCl}_{4}$-intoxicated rats revealed hepatic necrosis and hemorrhage, inflammatory cell infiltrating, and cell swelling (Fig. 1B). Compared with the lesions observed in the vehicle-treated $\mathrm{CCl}_{4}$ control group, the hepatic lesions of the $\mathrm{CCl}_{4}$-intoxicated rats pretreated with $10 \mathrm{mg} / \mathrm{kg}$ EFIO were markedly milder (Fig. 1C). Amelioration of hepatic necrosis in $\mathrm{CCl}_{4}$ intoxicated rats pretreated with $50 \mathrm{mg} / \mathrm{kg}$ EFIO was evident in the liver (Fig. 1D). Liver tissues were further analyzed to assess the fatty changes in $\mathrm{CCl}_{4}$-intoxicated rats (Fig. 2). In normal controls (Fig. 2A) and rats treated solely with either 10 or $50 \mathrm{mg} / \mathrm{kg}$ EFIO (data not shown), Oil-red-O staining did not reveal typical lipid droplets in the examined livers. In the vehicle-treated and $\mathrm{CCl}_{4}$-intoxicated group, Oil-red-O staining revealed diffuse fatty degeneration throughout the liver (Fig. 2B). In contrast, pretreatment with either $10 \mathrm{mg} / \mathrm{kg}$ EFIO 


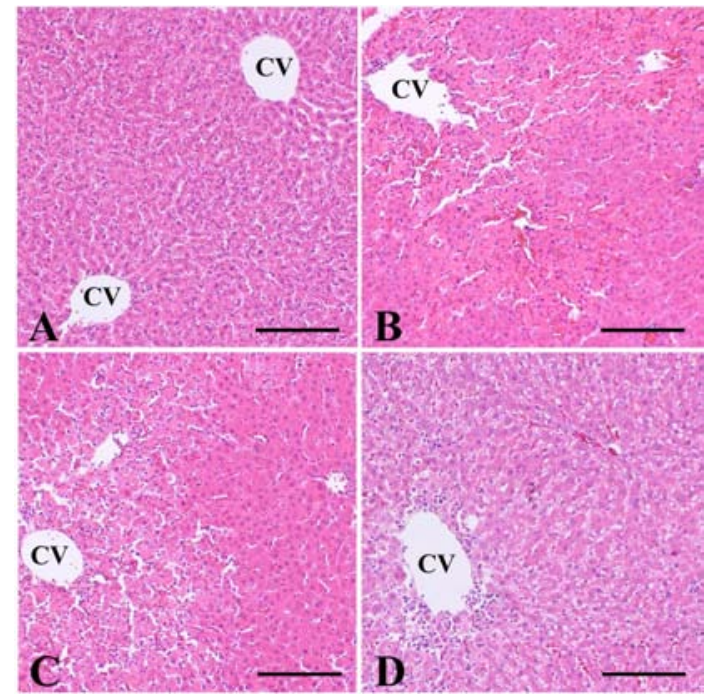

Fig. 1. Effect of EFIO on hepatic histology in $\mathrm{CCl}_{4}$ intoxicated rats. Livers were sectioned and stained. (A) Normal control, (B) vehicle $+\mathrm{CCl}_{4}(3.3 \mathrm{~mL} / \mathrm{kg})$ control, (C) EFIO $(10 \mathrm{mg} / \mathrm{kg})+\mathrm{CCl}_{4}$, (D) EFIO $(50 \mathrm{mg} / \mathrm{kg})+\mathrm{CCl}_{4}$. $\mathrm{H} \& \mathrm{E}$ stain, Scale bars $=100 \mu \mathrm{m}$.

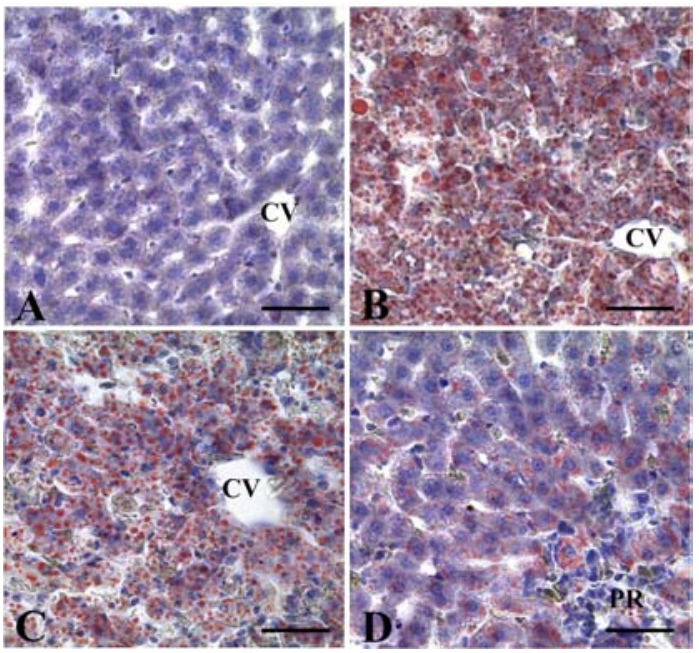

Fig. 2. Effect of EFIO on $\mathrm{CCl}_{4}$-induced acute fatty change. Liver sections were stained. (A) Normal control, (B) vehicle $+\mathrm{CCl}_{4}(3.3 \mathrm{~mL} / \mathrm{kg})$ control, (C) EFIO $(10 \mathrm{mg} / \mathrm{kg})+$ $\mathrm{CCl}_{4}$, (D) EFIO $(50 \mathrm{mg} / \mathrm{kg})+\mathrm{CCl}_{4}$. Oil red O stain, Scale bars $=50 \mu \mathrm{m}$.

Table 3. Effects of EFIO on histopathology of $\mathrm{CCl}_{4}$-induced liver injury in rats

\begin{tabular}{lcccc}
\hline \hline \multirow{2}{*}{ Parameter } & \multicolumn{4}{c}{ Group } \\
\cline { 2 - 5 } & Control & EFIO $(50 \mathrm{mg} / \mathrm{kg})$ & $\mathrm{CCl}_{4}(3.3 \mathrm{~mL} / \mathrm{kg})$ & $\mathrm{EFIO}(50 \mathrm{mg} / \mathrm{kg})+\mathrm{CCl}$ \\
\hline Hemorrhage $^{\mathrm{a}}$ & $-{ }^{\mathrm{c}}$ & - & ++ & + \\
Hepatocyte necrosis $^{\mathrm{a}}$ & - & - & +++ & ++ \\
Infiltration of inflammatory cells $^{\mathrm{a}}$ & - & - & +++ & ++ \\
Fatty degeneration $^{\mathrm{b}}$ & - & - & +++ & +
\end{tabular}

Rats were pretreated with EFIO (10 or $50 \mathrm{mg} / \mathrm{kg}$, i.p.) once daily for 2 consecutive days. $24 \mathrm{~h}$ after the final treatment, the rats were treated with $\mathrm{CCl}_{4}\left(3.3 \mathrm{~mL} / \mathrm{kg}\right.$, i.p.). Histopathological examination was performed $24 \mathrm{~h}$ after $\mathrm{CCl}_{4}$ treatment. ${ }^{\mathrm{a}} \mathrm{For}$ estimation of hemorrhage, hepatocyte necrosis, and infiltration of inflammatory cells, livers were sectioned and stained with hematoxylin and eosin by standard techniques. ${ }^{b}$ For estimation of fatty degeneration, liver were sectioned and stained with Oil red O stain by standard techniques. ${ }^{c}$ Grades: - , absent; +, trace (1 25\%); ++, weak (26 50\%); +++, moderate (50 75\%); ++++ , severe $(75 \sim 100 \%)$.

(Fig. 2C) and $50 \mathrm{mg} / \mathrm{kg}$ EFIO (Fig. 2D) reduced the fatty change in the livers of rats treated with $\mathrm{CCl}_{4}$. Especially, $50 \mathrm{mg} / \mathrm{kg}$ EFIO pretreatment markedly decreased the fatty changes of the periportal region (Fig. 2D). Histopathologic examinations (hemorrhage, hepatocyte necrosis, infiltration of inflammatory cells, and fatty degeneration) based on above histological findings were recorded and scored (Table 3).

\section{Immunohistochemical localization of ED1-posi- tive macrophages}

To determine the effect of EFIO on the localization of monocyte-like hepatic macrophages (Kupffer cells) in $\mathrm{CCl}_{4}$-induced acute liver injury, immunoreactivity of ED1-positive macrophages in the liver was assessed. ED1-positive reaction occurred only very rarely in normal controls (Fig. 3A). In vehicle-treated and $\mathrm{CCl}_{4^{-}}$ intoxicanted rats, ED1-positive cells were uniformly distributed across the liver lobule following $\mathrm{CCl}_{4}$ treatment (Fig. 3B). However, in samples from rats pretreated with $50 \mathrm{mg} / \mathrm{kg}$ EFIO, ED1-positive cells were markedly decreased and were localized almost exclusively in the centrilobular region of the liver (Fig. 3C). 


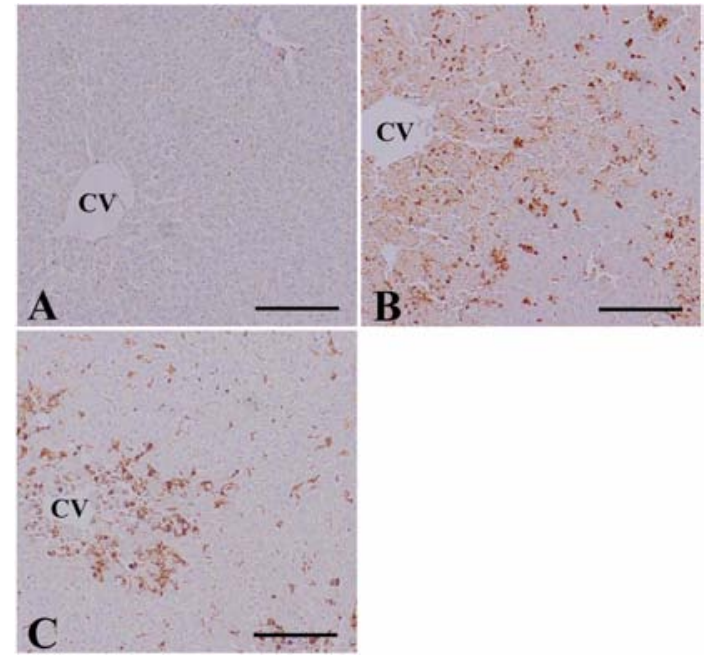

Fig. 3. Immunohistochemical staining of ED1-positive macrophages in the liver of rat with $\mathrm{CCl}_{4}$ treatment. (A) Normal control, (B) vehicle $+\mathrm{CCl}_{4}(3.3 \mathrm{~mL} / \mathrm{kg})$ control, (C) EFIO $(50 \mathrm{mg} / \mathrm{kg})+\mathrm{CCl}_{4}$. Scale bars $=200 \mu \mathrm{m}$.

\section{Discussion}

In the present study, the capability of EFIO to protect against $\mathrm{CCl}_{4}$-induced hepatic injury was investigated in a rat model. It has been reported that the ethanolic extract of $I$. okamurae exert an anti-inflammatory effect by inhibiting nuclear factor-kappa B (NF-kB) [11]. Lots of anti-oxidant compounds including fucoxathin [10] and diphlorethohydroxycarmalol $[1,8]$ have been identified in the EFIO. Thus it is highly possible that EFIO modulates the liver injury induced by $\mathrm{CCl}_{4}$. It is because the metabolites of $\mathrm{CCl}_{4}$ formed by cytochrome $\mathrm{P}-450$ enzyme, including trichloromethyl radicals $\left(\cdot \mathrm{CCl}_{3}\right)$ and trichloromethyl peroxyl radicals $\left(\mathrm{Cl}_{3} \mathrm{COO} \bullet\right)$, have been demonstrated to initiate peroxidation and have effect on liver pathogenesis [13]. Many studies have revealed that a single compound from natural products reduced $\mathrm{CCl}_{4}$-induced hepatic injury $[6,9]$. The results favor the suggestion that a major hepatoprotective mechanism of such compounds is associated with their antioxidant abilities. In vitro and in vivo studies have shown that DPHC isolated from EFIO has anti-oxidative activity $[1,7,8]$. In the present study, EFIO treatment significantly prevented $\mathrm{CCl}_{4}$-induced liver damage as evidenced by decreased serum activities of ALT and AST. Additionally, we also examined the liver activities of SOD and CAT, which are the major antioxidant enzymes responsible for elimination of reactive oxygen species. EFIO treatment restored SOD and CAT activities, most probably due to its strong free radical chelating potency. Therefore, we suggest that $\mathrm{EFIO}$ prevents $\mathrm{CCl}_{4-}$ induced injury in rat liver, possibly via the inhibition of oxidative stress.

In the present histological examinations, $\mathrm{CCl}_{4}$-treated liver examined by H\&E and Oil-red-O staining displayed characteristics of significant hepatotoxicity, including hemorrhage, hepatocyte necrosis, infiltration of inflammatory cells, and fatty degeneration, similar to previous histopathological findings [6, 9]. However, EFIO treatment significantly decreased these reactions in rat liver, suggesting that EFIO provides protection against $\mathrm{CCl}_{4}$-induced hepatic injury.

In addition, $\mathrm{CCl}_{4}$-induced injury is characterized by direct and indirect sequential phases in the liver [3, 4]. An indirect secondary damage originates from activated hepatic macrophages (Kupffer cells) through the release of inflammatory mediators [3]. An ethanol extract of $I$. okamurae and a fucoxanthin isolated from EFIO inhibit inflammation via inactivation of NF-kB transcription factor in macrophages $[10,11]$. In the present study, in $\mathrm{CCl}_{4}$-intoxicated rats, EFIO treatment altered the pattern of ED1 immunoreactivity from a widespread distribution to reduced total numbers and localization of the remaining cells around the central vein. This shift and the anti-inflammatory effect might contribute to the inhibitory effect of EFIO in $\mathrm{CCl}_{4}$-induced hepatic injury.

In conclusion, EFIO is effective in alleviating $\mathrm{CCl}_{4^{-}}$ induced liver injury in a rat model as evidenced by decreasing ALT and AST serum levels, increased SOD and CAT activities, and inhibition of histological damage and macrophage infiltration in the liver. The inhibitory effects of EFIO may be exploited in the use of the compound in the hepatoprotection against chemicalinduced hepatotoxicity in vivo. However, further studies will be needed to establish the molecular mechanism of the protective effect of EFIO on hepatocytes in $\mathrm{CCl}_{4}{ }^{-}$ induced liver injury.

\section{References}

1. Ahn M, Moon C, Yang W, Ko EJ, Hyun JW, Joo HG, Jee Y, Lee NH, Park JW, Ko RK, Kim GO, Shin T. Diphlorethohydroxycarmalol, isolated from the brown algae Ishige okamurae, protects against radiation-induced cell damage in mice. Food Chem Toxicol 2011, 49, 864-870. 
2. Carrillo MC, Kanai S, Nokubo M, Kitani K. (-) Deprenyl induces activities of both superoxide dismutase and catalase but not of glutathione peroxidase in the striatum of young male rats. Life Sci 1991, 48, 517-521.

3. Edwards MJ, Keller BJ, Kauffman FC, Thurman RG. The involvement of Kupffer cells in carbon tetrachloride toxicity. Toxicol Appl Pharmacol 1993, 119, 275-279.

4. elSisi AED, Earnest DL, Sipes IG Vitamin A potentiation of carbon tetrachloride hepatotoxicity: role of liver macrophages and active oxygen species. Toxicol Appl Pharmacol 1993, 119, 295-301.

5. Halliwell B, Gutteridge JMC. The importance of free radicals and catalytic metal ions in human diseases. Mol Aspects Med 1985, 8, 89-193.

6. Hayashi S, Itoh A, Isoda K, Kondoh M, Kawase M, Yagi K. Fucoidan partly prevents $\mathrm{CCl}_{4}$-induced liver fibrosis. Eur J Pharmacol 2008, 580, 380-384.

7. Heo SJ, Hwang JY, Choi JI, Han JS, Kim HJ, Jeon YJ. Diphlorethohydroxycarmalol isolated from Ishige okamurae, a brown algae, a potent $\alpha$-glucosidase and alpha-amylase inhibitor, alleviates postprandial hyperglycemia in diabetic mice. Eur J Pharmacol 2009, 615, 252-256.

8. Heo SJ, Kim JP, Jung WK, Lee NH, Kang HS, Jun EM, Park SH, Kang SM, Lee YJ, Park PJ, Jeon YJ. Identification of chemical structure and free radical scavenging activity of diphlorethohydroxycarmalol isolated from a brown alga, Ishige okamurae. J Microbiol Biotechnol 2008, 18, 676-681.
9. Hsu YW, Tsai CF, Chuang WC, Chen WK, Ho YC, Lu FJ. Protective effects of silica hydride against carbon tetrachloride-induced hepatotoxicity in mice. Food Chem Toxicol 2010, 48, 1644-1653.

10. Kim KN, Heo SJ, Yoon WJ, Kang SM, Ahn G, Yi TH, Jeon YJ. Fucoxanthin inhibits the inflammatory response by suppressing the activation of NF- $\mathrm{KB}$ and MAPKs in lipopolysaccharide-induced RAW 264.7 macrophages. Eur J Pharmacol 2010, 649, 369-375.

11. Kim MM, Rajapakse N, Kim SK. Anti-inflammatory effect of Ishige okamurae ethanolic extract via inhibition of NF- $\mathrm{B}$ transcription factor in RAW 264.7 cells. Phytother Res 2009, 23, 628-634.

12. Lee IK, Kang JW. A check list of marine algae in Korea. Korean J Phycol 1986, 1, 311-325.

13. McCay PB, Lai EK, Poyer JL, DuBose CM, Janzen EG. Oxygen- and carbon-centered free radical formation during carbon tetrachloride metabolism. Observation of lipid radicals in vivo and in vitro. J Biol Chem 1984, 259, 2135-2143.

14. Misra HP, Fridovich I. The role of superoxide anion in the autoxidation of epinephrine and a simple assay for superoxide dismutase. J Biol Chem 1972, 247, 3170-3175.

15. Pérez Tamayo R. Is cirrhosis of the liver experimentally produced by $\mathrm{CCl}_{4}$ and adequate model of human cirrhosis? Hepatology 1983, 3, 112-120.

16. Zou Y, Qian ZJ, Li Y, Kim MM, Lee SH, Kim SK. Antioxidant effects of phlorotannins isolated from Ishige okamurae in free radical mediated oxidative systems. J Agric Food Chem 2008, 56, 7001-7009. 